\title{
Kinas nye tobarns-politik
}

\section{Jens-Peter Fage Madsen}

\section{Historien vil huske Kinas etbarns-politik som det mest ekstreme eksempel i moderne tid på statslig indblanding i menneskets reproduktion, og den vil blive sidestillet med de andre dødelige fejl- tagelser i den moderne kinesiske historie}

I forbindelse med en diskussion af den kinesiske etbarns-politik ville udtalelsen "et barn er nok" blive forbundet med myndighedernes kampagner for etbarns-politikken. Sådan forholder det sig imidlertid ikke altid. Udtalelsen her stammer fra nogle unge forældre, der selv er vokset op under etbarns-politikken. De har vænnet sig til et liv som enebørn og betragter det at være enebørn som det normale.

Den samme gruppe unge mennesker i den fødedygtige alder står også bag snusfornuftige udtalelser som "det er bedre at opfostre et barn ordentligt end at have mange børn, som man ikke kan tage sig ordentligt af". Andre bruger helt andre (magelige/egoistiske) argumenter imod det at få flere børn; "vi vil ikke bruge hele vores liv til at arbejde for at forsørge (vores barn/børn) ... Vi vil have mere ud af livet end dette".
Ovenstående tre udtalelser er alle citeret fra en artikel i Time Magazine fra december 2013, kort tid efter at den nyeste ændring af befolkningspolitikken blev vedtaget af Kinas Kommunistiske Parti.

\section{Xi Jinpings reformer}

Ændringen af befolkningspolitikken, der går under navnet tobarnspolitikken, er en del af en samlet reformpakke, der skal vise, i hvilken retning den nye ledelse under $\mathrm{Xi}$ Jinping ønsker at bevæge Kina.

Ved fremlæggelsen af det 60 punkts store reformforslag - et af de største reformprogrammer i Kinas nyeste historie - slog den kinesiske ledelse fast, at den kurs Kina havde bevæget sig på siden Deng Xiaopings økonomiske reformer i slutningen af 1970'erne er den korrekte kurs for Kina. Den overordnede lin- 
je vil fremover være den samme, men der er trods dette behov for justeringer af politikken på en række områder.

Derfor reformpakken, der indeholder såvel økonomiske som ikke$\varnothing$ konomiske reformer. De økonomiske betyder i hovedtrækkende en cementering af den hidtidigt førte økonomiske politik. Den nye ledelse under Xi Jinping vedstår sig altså arven fra Deng Xiaoping over Jiang Zemin til Hu Jintao. Dog har der sneget sig en lille, men meget betydningsfuld ændring ind i teksten. Før sagde man, at 'markedet var vigtigt' for $\varnothing$ konomien. Nu hedder det sig, at 'markedet er bestemmende' i økonomien.

Hvor bogstaveligt denne ændring skal tages, må fremtiden vise. Inden for det økonomiske område lægges der op til, at det for fremtiden skal gøres lettere at investere i statslige virksomheder. Ligeledes vil der komme en justering af landbrugsreformerne, der vil sikre bøndernes ejendomsret til jorden, hvilket vil komme til at betyde, at salg og arv af jord gøres lettere.

De ikke-økonomiske reformer rokker ikke ved kommunistparties magtmonopol, men lægger op til justeringer på enkeltområder. Inden for det politiske område vil det på sigt blive lidt lettere at lave politisk arbejde uden for kommunistpartiets snærende ramme. Det skal således gøres lettere at danne statsuafhængige foreninger, $\mathrm{fx}$ arbejdsgiverfor- eninger, fagforeninger og foreninger med et socialt formål.

Der vil blive gennemført en retsreform, der kommer til at betyde, at færre bliver anbragt i politiske fængsler. I forlængelse heraf er det også hensigten, at Kina i fremtiden vil anvende dødsstraffe mindre flittigt.

\section{Befolkningspolitikken}

Endeligt kommer der så den ovenfor skitserede reform af befolkningspolitikken, idet Kina vil gå fra den hidtidige etbarns-politik til en ny tobarns-politik. Erfaringer fra Kina viser, at et så omfattende reformkompleks vil kræve en endog meget lang indkøringsperiode. Reformforslaget taler selv om 2020 som en realistisk deadline. Den lange deadline kommer dog ikke til at gælde ændringerne i befolkningspolitikken. Ifølge den kinesiske sundhedsstyrelse træder den nye tobarns-politik nemlig i kraft allerede i januar 2014.

Med overgangen til tobarns-politikken bliver det med et slag lovligt for unge par at få to børn, hvis blot den ene part selv er enebarn. Hvor dramatisk og epokegørende lovændringen er, ses tydeligt, hvis man vender sig mod befolkningspolitikken, sådan som den blev formuleret i 1979 .

Dengang lanceredes sloganet 'senere, færre og bedre'. Hermed mentes, at familierne skulle have børn senere i livsforløbet. De skulle 
have færre børn - som hovedregel kun et barn. At følge dette var efter kommunistpartiets mening en klar forudsætning for et bedre liv (læs: højere levestandard) for den almindelige befolkning.

Politikken blev fra starten håndhævet ved at anvende pisk og gulerod. Til de familier, der levede op til politikken, var der hjælp fra staten i form af gratis skolegang (i grundskolen), lettere adgang til sundhedsvæsenet m.m. Det var guleroden. De familier, der ikke levede op til politikken, blev derimod straffet af staten og de lokale myndigheder gennem forfølgelse, store bøder, tvangsaborter, tvangssterilisationer, tvungne sundhedstjek med det formål at opdage graviditeter $\mathrm{mm}$.

Myndighedernes fantasi var stor, når det gjaldt om at svinge pisken for at håndhæve politikken. Udgangspunktet for politikken var en antagelse af, at den var nødvendig for at dæmpe befolkningstilvæksten, således at Kina på sigt kunne forblive stort set selvforsynende med fødevarer.

I praksis skete der op gennem 1980'erne, 90'erne og 00'erne små justeringer og lempelser af politikken. Således blev det hurtigt en accepteret kutyme, at landbefolkningen kunne få barn nummer to, under forudsætning af at det første barn var en pige eller var fysisk- eller psykisk handicappet. Det betød reelt, at ganske mange familier på landet på lovlig vis valgte at få to børn, da børnene jo også var en værdifuld arbejdskraft.

Denne undtagelse blev siden fulgt op med en lempelse, der betød, at man i familier, hvor begge forældre selv var enebørn, kunne tillades at få to børn. Denne undtagelse gjaldt såvel på landet som i byen. Endeligt var de etniske minoriteter fra starten undtaget fra etbarns-politikken. Med til historien hører også, at etbarns-politikken langt fra var det første eksempel i folkerepublikkens historie på, at staten har ført en aktiv befolkningspolitik. De fleste af disse befolkningspolitiske tiltag har som mål haft at begrænse befolkningstilvæksten. Undtagelsen fra dette var den befolkningspolitik, der blev ført under Det Store Spring Fremad (1958-62).

\section{Ægget eller hønen?}

Der har i tidens løb været gjort mange forsøg på at sætte tal på konsekvenserne af befolkningspolitikken. Dette lader sig naturligvis meget vanskeligt gøre, idet fertiliteten i ethvert samfund vil udvise udsving fra år til år, uanset om man fører en aktiv befolkningspolitik eller ej. Årsagerne til sådanne udsving vil ofte være irrationelle og derfor vanskelige at identificere.

Det eneste man kan gøre, er at sammenligne det faktiske befolkningstal i et år med en fremskrivning af befolkningstallet fra det år befolkningspolitikken blev startet. 
Laver man sådanne beregninger på Kinas befolkningstal i dag, kan man konstatere, at Kina i dag har et befolkningstal, der ligger ca. 400 mio. under det estimerede befolkningstal uden etbarns-politikken. Med andre ord er der i dag 400 mio. færre munde at mætte i Kina, end der havde været, hvis man ikke havde indført etbarns-politikken. Så målt på væksten i befolkningstallet har etbarnspolitikken været en utvetydig succes.

Faldet i befolkningstilvæksten dækker over, at fertiliteten i Kina er faldet dramatisk. Efter revolutionen i 1949 lå fertiliteten i Kina på ca. 6, dvs. de kinesiske kvinder fødte hver i gennemsnit seks børn. I midten af 1960'erne, da fertiliteten toppede, fødte de kinesiske kvinder i gennemsnit ca. 7,5 børn. I dag er fertiliteten efter mere end 30 år med etbarns-politikken på ca. 1,55. Til sammenligning er fertiliteten i Danmark 1,87 barn pr. kvinde. Den lave fertilitet betyder, at en ung familie end ikke reproducerer sig selv.

Alt andet lige vil en så lav fertilitet betyde, at gennemsnitsalderen i Kina langsomt, men sikkert vil vokse. En proces der i perioden er blevet forstærket af, at den gennemsnitlige levealder i landet er steget bl.a. pga. bedre kost og sundhed. Samlet betyder det, at Kina i løbet af en kort årrække løber ind i et aldersboom, der er langt større end den såkaldte ældrebyrde, vi i Danmark bekymrer os om.

Tallet 400 mio. rummer dog også en meget dyster bagside. I samme periode er der gennemført ca. 335 mio. registrerede aborter (hertil kommer et ukendt antal illegale aborter) og ca. 200 mio. mere eller mindre frivillige sterilisationer. I samme åndedrag kan man da også spørge, om de 400 mio. færre fødsler rent faktisk skyldes etbarns-politikken. Erfaringerne fra andre samfund i verden har nemlig vist, at børnetallet automatisk falder, når levestandarden stiger. Og netop perioden efter 1978 har været kendetegnet ved en vækstperiode i kinesisk økonomi uden sidestykke i landets nyere historie.

Kritikere af etbarns-politikken har således hævdet, at der var kommet et fald i befolkningstilvæksten helt af sig selv, uden at man havde ført etbarns-politikken. Andre kritikere af etbarns-politikken hævder, at tallet 400 mio. primært er fremkommet ved, at beregningen er lavet med udgangspunkt i året 1970, og da fertiliteten i Kina allerede i 1970'erne (før etbarns-politikkens indførsel) faldt meget kraftigt, ville man være nået tæt på tallet 400 mio., uanset om man havde indført etbarns-politikken eller ej.

En kinesisk befolkningsekspert Mu Guangzong siger således, at højst en fjerdedel af faldet i befolkningstilvæksten kan tilskrives etbarns-politikken. De tre fjerdel skyldes den øgede levestandard kombineret med bedre og mere udbredte svangerskabsforebyggende metoder. 
Holder denne argumentation, har etbarns-politikken påført befolkningen store lidelser uden påviselige resultater. Hertil svarer tilhængerne af etbarns-politikken, at etbarns-politikken har været forudsætningen for væksten og derfor en nødvendig brik, hvis puslespillet skulle gå op. Mest af alt minder opgøret om etbarns-politikken om diskussionen af, hvad der kom først: hønen eller ægget.

Som nævnt i starten af teksten er der i dag rigtig mange unge mennesker, der er vokset op med etbarnspolitikken og betragter den som en fornuftig og naturlig politik. Det er en gruppe unge, der af forskellige grunde ikke ønsker at få flere børn - de prioriterer materielle goder højere end flere børn. For dem vil en liberalisering af etbarns-politikken sandsynligvis ikke få nogen som helst betydning.

\section{Inerti og vanetænkning}

Men det er ikke den eneste grund til, at det kan være vanskeligt at få de kinesiske kvinders fertilitet hævet. Etbarns-politikken har betydet, at der i løbet af de sidste 20-30 år er vokset et gigantisk bureaukrati op, der lever af at administrere politikken. Det anslås, at op mod 500.000 embedsmænd direkte eller indirekte lever af at administrere etbarnspolitikken på lokal-, regional- eller landsplan.

Disse mange embedsmænd vil næppe uden sværdslag overflødigg øre sig selv. Således kan man sagtens forestille sig, at de også i fremtiden vil forsøge at overbevise såvel regionale som centrale myndigheder om, at det fortsat er nødvendigt at holde børnetallet nede, og at deres kontrolmyndig derfor fortsat er nødvendig. Embedsmændene kan endeligt fremføre det argument, at håndhævelsen af etbarns-politikken hidtil har medført, at de kinesiske borgere har betalt over 2000 mia. Yuan (ca. 1800 mia. d.kr.) i bøder for overtrædelse af lovgivningen.

Embedsmændenes og myndighedernes manglende lyst til at føre den nye lovgivning ud i livet kan sammen med de unge kineseres 'vanetænkning' let føre til, at lovændringen i hvert fald på kort sig kan få en begrænset virkning.

Derfor må man selvfølgelig spørge: Hvilke konsekvenser vil en fortsat meget lav fødselsrate have?

\section{Uoverskuelig forsørgerbyrde}

For det første vil den mangel på arbejdskraft, der allerede er en realitet, blive kraftigt forstærket, hvis fødselstallet ikke vokser. Mangel på arbejdskraft i en situation, hvor den kinesiske økonomi vokser med de høje vækstrater, vi har set de sidste 20 år, vil få alvorlige konsekvenser.

I de sidste to årtier har den årlige vækstrate ligget på 7-14 pct. Skal dette fortsætte, kræves der tilgang af arbejdskraft. Det er i kystregionerne 
væksten og dermed behovet for arbejdskraft har været absolut størst. Hidtil har man kunnet kompensere for manglen på arbejdskraft bl.a. ved at hente arbejdskraft fra indlandsprovinserne til kystområderne.

Men selv denne tilførsel af arbejdskraft har ikke kunnet forhindre arbejdskraftmangelen i at slå igennem. Konsekvensen har været et stigende lønniveau. Udviklingen forstærkes yderligere af, at efterspørgslen efter arbejdskraft også omfatter uddannet arbejdskraft. Den arbejdskraft, der har kunnet hentes fra indlandsprovinserne, er primært uuddannet arbejdskraft.

Efterspørgslen efter arbejdskraft har ydermere fået mange unge fra fattige hjem til at forlade grundskolen uden tilstrækkelige skolekundskaber. De er blevet 'lokket' fra skolebænken til virksomhederne af et job med løn. Det vil i fremtiden yderligere gøre det svært at skaffe veluddannet arbejdskraft. Den lave fødselsrate kan dermed fremadrettet udgøre en trussel mod landets økonomiske vækst.

Dernæst er den lave fødselsrate og den højere gennemsnitslevealder med til at give den unge generation en nærmest uoverskuelig fors $\varnothing$ rgerbyrde. Man taler her om den såkaldte 1:2:4-effekt. Hermed menes, at hvert ungt menneske skal skaffe indtægter til at forsøge sig selv og sit barn plus to forældre og op til fire bedsteforældre. Det vil sige, at et ungt par tilsammen skal forsørge et barn, op til fire forældre og op til otte bedsteforældre.

Denne effekt ses tydeligt, hvis man ser på de unges forsørgerbyrde. FN lavede i 2007 en fremskrivning over forsørgerbyrdens udvikling frem mod 2050. Figuren viser med al ønskelig tydelighed proble-

\section{Forsørgerbyrden i Kina frem mod 2050.}

Antal personer mellem 15 og 59 år per person over 60 .

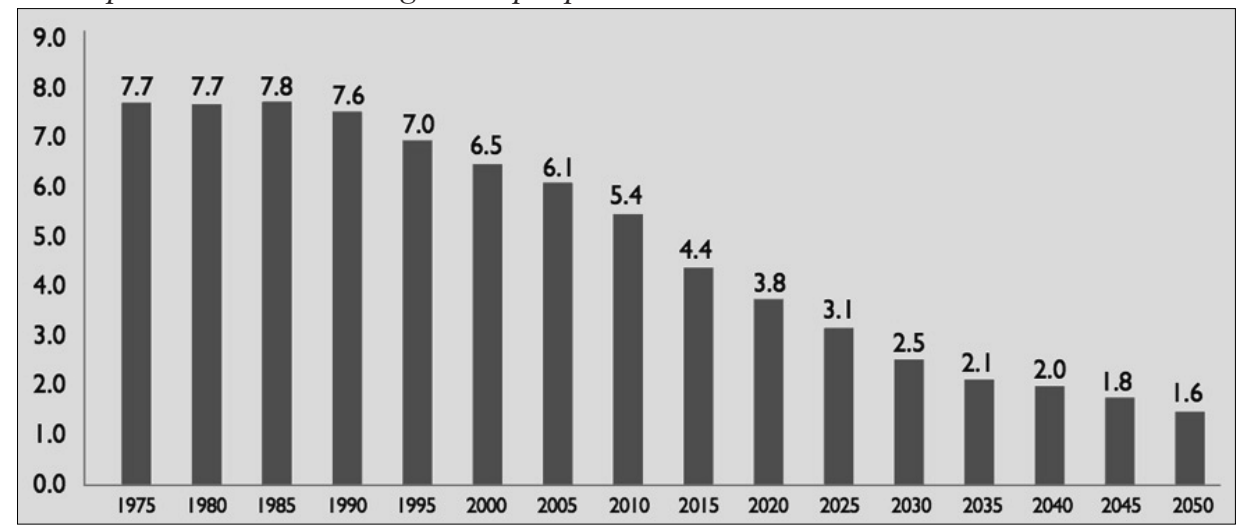


met. Hvor der i 1970'erne og 1980'erne var 7,7-7,8 unge pr. ældre, der skulle forsørges, er dette tal i dag nede på omkring 5 . I fremtiden vil det yderligere falde, således at det omkring 2050 når helt ned på 1,6.

Ser man blot frem til 2030'erne fortæller prognoserne, at antallet af ældre (over 65 år) vil være fordoblet til 400 mio. Samtidig vil antallet af unge (15-64 årige) falde med 200 mio. fra en mia. til under 800 mio. Hvis ikke staten på sigt overtager en del af denne forsørgerbyrde, vil de unges muligheder for og lyst til at få flere børn på ingen måde øges.

Det skal dog siges, at staten specielt de sidste 10-15 år har taget fat på denne opgave. Der er således i den periode etableret en arbejdsløshedsforsikring, et pensionssystem, sundhedsforsikringer og minimumsydelser for de allerfattigste. Svagheden med de næunte ordninger er, at de som hovedregel kun gælder udvalgte dele af befolkningen - primært bybefolkningen. Dertil kommer, at flere af ordninger bygger på forsikringsprincippet, hvilket betyder, at de fattigste grupper ikke har råd til at være med.

\section{Skæv kønsfordeling}

Endeligt har etbarns-politikken forrykket balancen mellem antallet af mænd og kvinder i det kinesiske samfund.

Før 1980 blev der født 102-107 drenge for hver 100 piger. Det sva- rer ret præcist til de tilsvarende globale tal. I perioden efter 1980 er der opstået en ubalance, der har betydet, at antallet af drengefødsler er steget. Pigerne er simpelthen blevet valgt fra gennem aborter med kønnet som begrundelse. I $2010 \mathrm{blev}$ der således født 119 drenge for hver 100 piger. I 2012 var tallet faldet en smule til 117,7:100.

Når piger vælges fra, er der flere årsager hertil. Dels er drenge en mere værdifuld arbejdskraft end piger specielt i landbruget, dels er det drengenes lod at være den primære forsørger af forældrene, og dels har sønner altid i Kinas lange historie været foretrukket frem for døtre. Derfor er der mere status i at få drenge end piger.

Den teknologiske udvikling med små mobile ultralydsscannere, der kan fortælle de kommende forældre om barnets køn, har blot forstærket problemet. I Kina kan man naturligvis ikke officielt få en abort med kønnet som begrundelse, derfor er en stor del af sådanne aborter illegale. Konsekvenserne af den skæve kønsfordeling kan bedst ses, hvis der sættes nogle tal på problemet. Befolkningseksperten Mu Guangzong illustrerer det med udgangspunkt i officielle kinesiske tal på følgende måde:

- Mellem 1983 og 2010 blev der født 41 mio. flere drenge end piger.

- Mellem 2001 og 2010 blev der hvert år født 1.4 mio. flere drenge end piger. 
- I den del af befolkningen, der er født efter 1970, er der 206 ugifte mænd for hver 100 ugifte kvinder

- Blandt de 30-årige var der i 2010 ca. 12 mio. ugifte mænd mod blot 6 mio. ugifte kvinder

Undersøgelser viser ydermere, at der er en overhyppighed af ugifte (lavt uddannede) mænd, der er forblevet og ønsker at forblive i landområderne. De ugifte kvinder derimod søger i større grad mod byerne for at tage en uddannelse, få et arbejde og gifte sig med en mand fra byen.

For en bypige vil det være forbundet med statustab at gifte sig med en mand fra landet. Dermed vil antallet af ungkarle i landområderne også i fremtiden forblive højt. Problemet bliver yderligere forstærket af 'hukou-systemet', der blev indført tilbage i 1950 'erne, og giver enhver kineser status af enten at være 'bybo' eller 'landbo'. Bybopiger kan sagtens flytte ud på landet, men det vil de ikke, til trods for at det her ville være lettere at finde en ægtemand. Omvendt kan en 'landbo' (-mand) ikke umiddelbart flytte til byen. Det vil kræve en særlig tilladelse fra myndighederne, der oftest ikke ser ægteskab som en tilstrækkelig begrundelse for at give en sådan tilladelse.

Selv om der de senere år er sket lempelser i hukou-systemet, er dette stadig med til at forstærke kønsproblematikken. Nogle af de samfundsmæssige følger af den skæve kønsfordeling ses i dag i form af et stig- ende antal voldelige overfald/voldtægter, handel med kvinder, indsmugling af kvinder fra nabolande (primært Thailand og Vietnam) og social uro. Således er der meget ofte demonstrationer vendt imod myndighedernes håndtering af befolkningspolitikken.

Kønsuligheden ses også på ejendomsmarkedet, idet de mange ungkarle ser det at eje en bolig som en genvej til lettere at få sig en kone. Følgen er stigende ejendomspriser. Hvis den ændrede befolkningspolitik for alvor skal slå igennem, er det en forudsætning, at der for alvor bliver rokket ved holdningen til piger og drenge. Det skal simpelthen gøres mere statusbelagt at få piger. Skal det ske, skal staten overtage en del af forsørgelsen af de ældre. Befolkningspolitikken og socialpolitikken skal derfor i fremtiden samtænkes.

\section{Social kontrakt}

Er tobarns-politikken starten på den endelige afvikling af befolkningspolitikken? Wang Peian, der er viceminister for befolkningsområdet, siger således: “... De nye regler er ikke ensbetydende med en afvikling af familieplanlægningsprogrammet. Det vil opretholdes også på lang sigt... ".

Forudsætningen for på lang sigt at bevare befolkningens accept af befolkningspolitikken enten i form af etbarns- eller tobarns-politikken er, at der indgås en slags social kontrakt 
mellem kommunistpartiet og befolkningen, hvor begge parter accepterer hinandens synspunkter.

Kommunistpartiet skal acceptere, at befolkningen i stigende grad ønsker frihed til at bestemme over eget liv, og befolkningen skal acceptere, at kommunistpartiets magtmonopol ikke sættes til diskussion. Om det kommer til at gå således, vil afhænge af mange faktorer.

En væsentlig parameter er, om den økonomiske vækst fortsætter, idet denne sikrer styrets legitimitet. En anden er kommunistpartiets holdning til befolkningens frihedsrettigheder, dvs. menneskerettighedsspørgsmålet.

I denne forbindelse skal man huske på, at den nuværende ungdomsgeneration, der netop er født under etbarns-politikken, er en af de mest kritiske generationer i Kinas nyere historie. De forholder sig kritisk til den politiske, den økonomiske og den sociale udvikling i landet, og de giver udtryk for kritikken på de sociale medier.

Et eksempel på dette er et indlæg fra en anonym blogger, der bl.a. skriver “... Det er mærkeligt, hvordan menneskerettigheder fungerer her (i Kina) ... Vores regering tog vores grundlæggende rettigheder som gidsel ... og besluttede sig år tilbage for størrelsen af vores familier. $\mathrm{Nu}$ giver de beslutningsretten dryp- vis tilbage til os i en slags handel, og vi forventes at være taknemmelige og af hele vores hjerte sige tak...".

Indlægget fik kun lov til at ligge på internettet nogle få timer, men ikke desto mindre repræsenterer det et vigtigt, men også bemærkelsesværdigt synspunkt i debatten om befolkningspolitikken. En gruppe kinesiske forskere siger meget direkte, at familieplanlægningsprogrammet vil blive udfaset. Deres argument er, at individuelle rettigheder ikke i længden kan ignoreres af styret.

Hertil føjer de “... historien vil huske Kinas etbarns-politik som det mest ekstreme eksempel i den moderne æra på statsintervention $\mathrm{i}$ menneskets reproduktion ... Etbarns-politikken vil blive sidestillet med de andre dødelige fejltagelser i den moderne kinesiske historie, herunder hungersnøden i 1959-61 (under Det Store Spring Fremad) ... og Kulturrevolutionen i de sene 1960 'ere og de tidlige 1970'ere...".

Jens-Peter Fage Madsen er cand.mag. $i$ historie og Østasien områdestudiet fra Aarhus Universitet. Han har udgivet flere bøger om Kina, senest 'Ansigt til ansigt med kineserne (Pantheon 2010). August 2014 udsender han en bog om den allernyeste udvikling $i$ Kina. Han er ansat som lektor ved Frederikshavn Handelsgymnasium. 